\title{
Organic Compounds and Genotoxicity in Drinking Water
}

\section{A. Noordsij}

\section{J. van Genderen}

\section{J. van Beveren}


Organic Compounds and Genotoxicity in Drinking Water 


\section{KIWA: PROFILE AND MISSION}

Started in 1948, Kiwa Water Research has developed into an internationally respected research center in the field of drinking water and related environmental issues. The 120 scientific specialists conduct the joint research program of the water supply companies in the Netherlands, and also provide research services for other national and international clients.

While the major focus is on drinking water supply, Kiwa is also involved in projects addressing the integration of the water chain, including water for industrial and other use. Core tasks of the division include innovative research and transfer of knowledge and know-how.

Other divisions of Kiwa provide a range of certification, inspection and management consultancy services for water businesses and other sectors of industry.

More information can be found on www.kiwa.nl 


\section{Organic Compounds and Genotoxicity in Drinking Water}

A. Noorsij, J. van Genderen and J. van Beveren 
Published by IWA Publishing, Alliance House, 12 Caxton Street, London SW1H 0QS, UK

Telephone: +44 (0) 207654 5500; Fax: +44 (0) 207654 5555; Email: publications@iwap.co.uk

Web: www.iwapublishing.com

First published 2004

(c) 2004 KIWA

Printed by Ashford Overload, Southampton, UK

Apart from any fair dealing for the purposes of research or private study, or criticism or review, as permitted under the UK Copyright, Designs and Patents Act (1998), no part of this publication may be reproduced, stored or transmitted in any form or by any means, without the prior permission in writing of the publisher, or, in the case of photographic reproduction, in accordance with the terms of licences issued by the Copyright Licensing Agency in the UK, or in accordance with the terms of licenses issued by the appropriate reproduction rights organization outside the UK. Enquiries concerning reproduction outside the terms stated here should be sent to IWA Publishing at the address printed above.

The publisher makes no representation, express or implied, with regard to the accuracy of the information contained in this book and cannot accept any legal responsibility or liability for errors or omissions that may be made.

\section{Disclaimer}

The information provided and the opinions given in this publication are not necessarily those of IWA, KIWA or the editors, and should not be acted upon without independent consideration and professional advice. IWA and the editor will not accept responsibility for any loss or damage suffered by any person acting or refraining from acting upon any material contained in this publication.

British Library Cataloging in Publication Data

A CIP catalogue record for this book is available from the British Library

Library of Congress Cataloging- in-Publication Data

A catalog record for this book is available from the Library of Congress

ISBN: 1843390485 


\section{CONTENTS}

Summary 1

1 Introduction 3

1.1 Organic compounds in water 3

1.2 Classification of organic compounds 3

1.2.1 Hydrophobic compounds 4

1.2.2 Hydrophilic compounds 4

1.3 Mutagenicity and hydrophility 4

2 Associated experiments 6

2.1 Choice of water types for the research 6

2.2 Experimental set-up $\quad 7$

3 Results and discussion $\quad 8$

3.1 Description of the isolated material 8

3.2 Quantification of adsorbed organic material 9

3.3 Results of the Ames assay 9

3.4 The organic material and the mutagenicity in a scheme 11

3.5 Availability hypothesis 12

3.6 The influence of oxidation on the mutagenic effect 13

4 Conclusions 14

4.1 Origin and amount of the hydrophilic material 14

4.2 Mutagenicity 14

4.3 The meaning of the results to evaluate the drinking water quality and treatment 15 $\begin{array}{ll}\text { Literature } & 16\end{array}$

Appendix 1 The Ames test and the transport of compounds through biological 17 membranes

Appendix 2 Sampling locations and examined water types $\quad 20$

Appendix 3 Quantification of adsorbed organic material $\quad 21$

Appendix 4 Chromatografic characterisation of isolated material 23

Appendix 5 Results Ames test 26 



\section{SUMMARY}

Water quality management requires knowledge about all aspects that can have an impact on water quality. From toxicological point of view the presence of organic micro-pollutants in raw water and consequently drinking water, is one of these aspects. Taking into account that these compounds are usually found in relatively low concentrations, the main research attention of drinking water industry is focused on the (suspected) presence of mutagenic and carcinogenic compounds.

Up to now only lipophilic (= less soluble in water) compounds were analysed within research on the occurrence of mutagenic and carcinogenic compounds in water. These compounds were isolated from water using XAD-resins. It was proved that they contain approximately half of the total organic material present in water. A clear mutagenic effect was demonstrated for these compounds using the Ames test.

Up to now, the hydrophilic (= very good soluble in water) part of the organic material could be hardly included in the research. This material is namely difficult to isolate and analyse due to its high solubility. The high solubility means also that the hydrophilic compounds are mobile in conventional treatment systems and in water conveying (ground) pockets. They can easily penetrate into drinking water. Because of this, it is very important to know, what is the toxicological meaning of this hydrophilic material.

Eight different water types, including strongly polluted industrial water, were examined to determine the role of hydrophilic material. A method was developed to isolate these compounds using a combination of ion exchange concentration and a clean-up with a XADresin (van Beveren, 1999). The isolates obtained with this method were examined with the Ames assay for the presence of mutagenic (hydrophilic) compounds.

For some water types a mutagenic effect was found in the lipophilic material, isolated with XAD-4. Next to it, clear indications were attained that due to oxidation with ozone, mutagenic compounds can be formed from (not mutagenic) industrial pollutions. 
No mutagenic activity was found in the hydrophilic organic material of all examined water sorts, also not after oxidation with ozone or chlorination of the water.

Based on the results of this research and earlier performed experiments (Noordsij, 1996) as well as current knowledge on the role of biological membranes during uptake of compounds, a hypothesis was developed that hydrophilic compounds in water can not reach the DNA of the cell - they can hardly or not at all pass the cell membrane - and that is why they do not play any (geno) toxicological role. As a continuation it was stated that in the research on the occurrence and the identification of specific genotoxical compounds in water, attention has to be paid on the identification of the compounds positive scoring in the Ames test using LC/MS. It is hereby recommended to include in the research the effluent from the wastewater treatment plants from the point of surface water quality control in relation to drinking water.

Finally it was concluded that strongly lipophilic compounds can be converted by oxidation to mutagenic compounds. From this point it is recommended to determine with which methods and in which rate the lipophilic compounds can be removed before oxidation in the treatment scheme. 


\section{1}

\section{Introduction}

\subsection{Organic compounds in water}

To evaluate and control the quality of drinking water, it needs to be known whether the present compounds can influence this quality. Harmful organic compounds, originating for instance from industrial of agricultural activities, should be removed during the production of drinking water.

When toxic pollutants are acute present in high concentration in surface water, it should be rapidly and clearly detected using current (bio)detection systems. In this way the drinking water distribution industry can undertake just on time adequate actions to prevent against any risk for drinking water production.

It is relatively difficult to detect undesired compounds, which can cause a harmful effect already at low concentrations but after a longer time of exposure. These are, for instance, genotoxic compounds damaging the genetic material (DNA), possibly causing cancer or inducing genetic deviation.

The drinking water industry has invested a lot for the last two decades in the research to prevent the occurrence of genotoxic compounds in (drinking) water. The Ames test (Bacterial Reverse Mutation test with Salmonella typhimurium; OECD, 1997) served as a standard guideline, followed by identification of the relevant compounds. The identification, in turn, was followed by evaluation based on available literature data on health relevancy of detected pollutants.

\subsection{Classification of organic compounds}

The organic compounds present in water vary significantly. They differ regarding the size of molecules, polarity, solubility, acid- or base- character. 
The organic compounds can be divided based on their solubility into two main categories: lipophilic (less soluble) and hydrophilic (good soluble). In literature also the terms apolar and polar are respectively used for these groups of compounds.

Both main categories can be further divided into three types: neutral, acid and basic.

The solubility of a compound in water is of great importance for the quality of drinking water. The compounds well soluble in water are more difficult to remove. It is not only important for the treatment processes, but also by the isolation for the analytical-chemical and toxicological determinations.

\footnotetext{
The solubility of in water can be expressed by so-called $\log \mathrm{K}_{\mathrm{ow}}$-value of the regarded compound. This is a parameter reflecting the ratio between the solubility in solvent octanol and in water $\left(\mathrm{K}_{\mathrm{ow}}\right)$. When the $\log \mathrm{K}_{\mathrm{ow}}$ is 5 , it means that the compound is 100000 times better soluble in octanol than in water. A log $\mathrm{K}_{\text {ow }}$ of - 3 means that the compound is 1000 times better soluble in water than in octanol. Hydrophobic compounds have a log $\mathrm{K}_{\mathrm{ow}}$ higher than 0 , of hydrophilic compounds the $\log \mathrm{K}_{\mathrm{ow}}$ is lower than 0 . The first ones solve than better in water than in octanol.
}

\subsubsection{Hydrophobic compounds}

In the research carried out by KIWA, mainly lipophilic compounds were isolated from water and controlled for mutagenic potential using the Ames test and further identified with gas chromatography in combination with mass spectrometry (GC-MS).

The lipophilic compounds were isolated using the styrene divinylbenzene synthetic resin XAD-4 at pH 7 followed by pH 2 and/or pH 12. Depending on the water type, 30 to $60 \%$ of the TOC (Total Organic Carbon) can be isolated from water using this method (Noordsij, 1996). During looking for a mutagenic effect in a certain water type (surface water, chlorinated water and sometimes ground water) only a small amount of compounds possibly responsible for this effect can be determined. The total measured effect can however not be explained in this way. The mutagenic activity turned out to be located in the fraction of XAD isolates, which could not be measured by gas chromatography. The combination of liquid chromatography and mass spectrometry (LC-MS) is more suitable for identification of these isolates.

\subsubsection{Hydrophilic compounds}

Hydrophilic compounds cannot be isolated from water using XAD resins. They were thus up to now hardly involved in research. Because of their hydrophilic character they cannot be removed from raw water using conventional physical treatment techniques. Hydrophilic compounds can be also formed during natural degradation processes in the water itself or during production of drinking water, when enhanced oxidation processes such as ozone oxidation are implemented. Taking into account the evaluation of water quality, it is important to determine whether hydrophilic compounds form a potential genotoxical danger.

\subsection{Mutagenicity and hydrophility}

As already mentioned, the Ames assay is used to determine mutagenicity. A detailed description of this test, including belonging transport processes, is presented in appendix 1 .

In a large number of KIWA research projects the mutagenicity was determined in XAD isolates. Surface water (RIWA 1981 - 1987, van der Kooij, 1986, Noordsij and van Genderen, 1990), water after chlorination (Kruithof, 1984, Noij, 1989) and ground water (Veenendaal, 1987) and drinking water produced from each type of raw water, were tested. In situations whereby a mutagenic activity was found in XAD isolates, it turned out that it 
was not accidentally spread in the isolated material but located within a $\log \mathrm{K}_{\mathrm{ow}}$ range from 0.3 to 2.5 with a maximum at $\log \mathrm{K}_{\mathrm{ow}}$ value of approximately 1.3 (Noordsij, 1991 and 1996). Taking into account that the $\log \mathrm{K}_{\mathrm{ow}}$ value is a measure of the hydrophility of the compound, the mentioned pattern suggests that there is a relation between the occurrence of a mutagenic effect and the hydrophility of the compounds.

Thanks to the current knowledge on the transport of compounds through biological membranes it is stated that the mutagenic effect measured in the Ames test is until a certain level equal to the mutagenic potential determined by the molecular structure and the rate in which the considered compound passes the membrane (Noordsij, 1996). This report describes the results, which ground this hypothesis. 


\section{2}

\section{Associated experiments}

To verify the availability hypothesis, the hydrophilic organic material was isolated from the effluent of XAD-column of different water samples. This material was further verified using the Ames test for the presence of mutagenic compounds. The Ames assay was carried out with the strains TA98 and TA100, both with and without metabolic activation (see appendix 1). Mainly the acid hydrophilic material was involved in this research.

\subsection{Choice of water types for the research}

The research focussed to determine whether the mutagenicity is indeed limited to the lipophilic material isolated with XAD and whether the mutagenic effect is influenced by oxidation of lipophilic compounds. The water samples were selected in such a way that they, concerning the lipophilic part (taking into account earlier performed analysis), could be possibly very mutagenic in the Ames test (surface water from Rhine and Lekkanaal, Andijk water after chlorination) or not at all (drinking water, dune filtrate after oxidation with ozone).

To include in the research the effect of ozone oxidation on the mutagenic effect, dune filtrate where the lipophilic fraction was not expected to be mutagenic in the Ames test and also the industrially polluted water from river Rhine of which lipophilic compounds were clearly mutagenic in Ames test, were oxidized with ozone. It was also determined whether due to enhanced oxidation with ozone, mutagenic activity is induced in the hydrophilic fraction of the samples were no mutagenic effect was found in the lipophilic fraction. The hydrophilic material of all water types has not been earlier examined on genotoxicity.

The following water samples were examined:

- Drinking water Nieuwegein

- Lekkanaal water WRK 
- Rhine water from Germany at Bad Honnef (twice)

- Rhine water from Germany at Bad Honnef after oxidation with ozone

- GWA-Leiduin dune filtrate before ozone oxidation

- GWA-Leiduin dune filtrate after ozone oxidation

- PWN Water Andijk (Ijselmeer) after chlorination

(In appendix 2 more data are given regarding water samples)

\subsection{Experimental set-up}

The isolation- and conversion procedure for the hydrophilic compounds was performed according to the method described by Van Beveren and Noordsij (1999). This methodology can be summarized as follows (see also Figure 3.1):

1. Isolation of lipophilic compounds using XAD-4 at $\mathrm{pH} 7$ and 2;

2. The effluent of the XAD-isolation is after neutralization to $\mathrm{pH} 7$ led through an anion exchanger IRA-904, where the hydrophilic acids are bound;

3. Further, compounds bound to anion exchanger are being re-desorbed. This elution consists of a solution of inorganic and organic compounds (acids);

4. Using a XAD-1180 column (a synthetic resin comparable to XAD-4 but with larger pores) the inorganic and organic compounds from the elution of the ion exchanger will be separated from each other. Due to this the inorganic compounds together with the strong hydrophilic compounds will pass the XAD-1180 non-delayed, while the weak hydrophilic compounds will be delayed. The weak hydrophilic organic material that remained on the XAD-1180 will be re-desorbed with ethanol.

5. The recovered organic material will be concentrated by evaporation. 


\section{Results and discussion}

\subsection{Description of the isolated material}

The final concentrated isolate consists of weak hydrophilic, acid organic material (effluent of XAD4 and eluate from anion exchanger) and it fits regarding hydrophility to the $\mathrm{XAD}$ isolate at $\mathrm{pH} 7$ and $\mathrm{pH}$ 2. It is known that during isolation using a synthetic resin like XAD-1180 also size-exclusion can occur. In this case the smaller molecules will be retained in XAD-1180 preferably, and large molecule pass the column faster.

The differences in physical character of the isolated fractions are confirmed using a liquid chromatographic analysis, so called HPLC-fingerprint (Noij, 1998) that is carried out for the various fractions of one of the samples (Rhine water at Bad Honnef). The results of this are presented in appendix 4. The chromatograms expose differences in mobility through the chromatographic column, and in this way the hydrophilic character of the three isolates: the pattern of the hydrophilic material differ clearly from this of both lipophilic XAD isolates. This confirms that the hydrophilic material is a completely different fraction of the organic material in water than the lipophilic material isolated with XAD-4.

The working areas of the different isolation techniques are given schematically on the $\log \mathrm{K}_{\mathrm{ow}}$ scale in Figure 3.1.

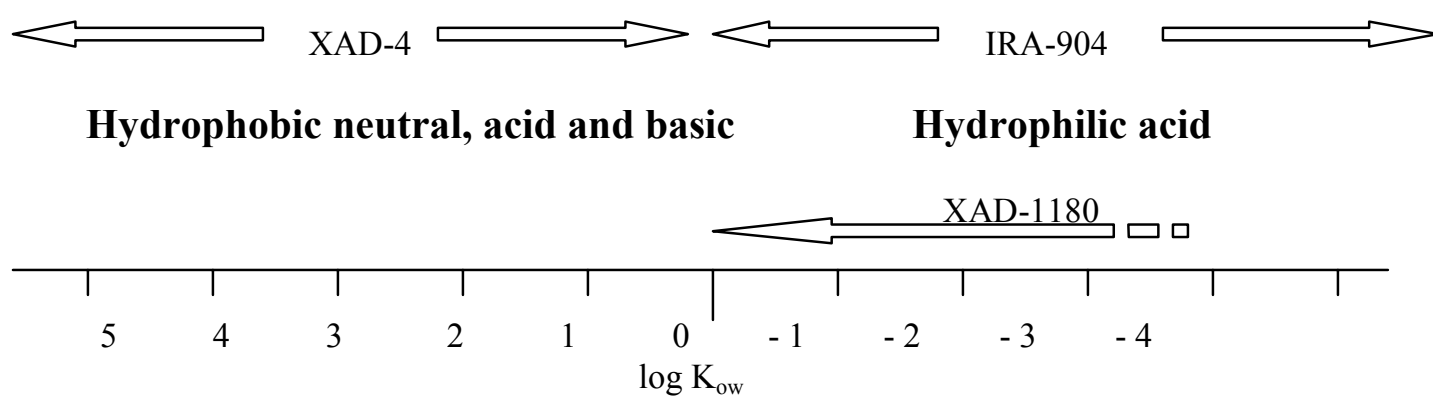

Figure 3.1 Operational ranges of XAD-4, IRA-904 and XAD-1180. 


\subsection{Quantification of adsorbed organic material}

UV measurements were performed in three water samples (drinking water, Lekkanaal and Bad Honnef I) in influent and effluent of the columns used in the experiments (see appendix 3). The average relative amounts of organic material in the different isolation steps are given in table 1.

Table 3.1 Relative composition of organic material

\begin{tabular}{|c|c|c|}
\hline Isolation step & character & $\%$ \\
\hline $\mathrm{XAD}-4$ at $\mathrm{pH} 7$ & Lipophilic neutral & 20 \\
\hline $\mathrm{XAD} 4$ at $\mathrm{pH} 2$ & Lipophilic acid & 30 \\
\hline $\mathrm{XAD} 4$ at $\mathrm{pH} 12$ & Lipophilic alkaline & $<$ \\
\hline IRA 904 & Totally hydrophilic acid & 40 \\
\hline Effluent IRA-904 & Hydrophilic neutral $\left.{ }^{*}\right)$ & $<$ \\
\hline IRA-904 + XAD-1180 & Weak hydrophilic acid**) & ca. 20 \\
\hline \multicolumn{3}{|c|}{$=$ this material is not possible to isolate from water with used techniques and not examined yet } \\
\hline \multicolumn{3}{|c|}{$\begin{array}{l}=\text { the least hydrophilic part of the hydrophilic acid organic material retained in IRA- } 904 \\
\text { approximately the half) }\end{array}$} \\
\hline \multicolumn{3}{|c|}{$=$ lower than the minimum measurable limit $(\mathrm{ca} .2 \%)$} \\
\hline
\end{tabular}

As given in Table 3.1 the hydrophilic neutral material was left out consideration in this research. Taking into account the character of this material and the fact that the balance estimations gave indications that it comprises less than 5\% of the total TOC (Noordsij, 1996), there is no reason to suspect that the referred compounds would influence the results and conclusions here presented. This counts possibly also for the very hydrophilic anions, which are elutriated together with the inorganic material from the XAD-1180.

The values given in Table 3.1 confirm the earlier stated global distribution of the organic material through the various fractions (Noordsij, 1996).

\subsection{RESULTS OF THE AMES TEST}

The results of the Ames tests are given in Tables 3.2 and 3.3. In appendix 5 there are results of the Ames test given as numbers of revertants per litre water. The values are corrected for the number of spontaneous revertants in the test. A mutagenic effect is found when the number of induced revertants is twice as high as the number of spontaneous revertants and when a relation dose-response effect has a correlation coefficient of $>0.70$.

The mark "_“" in Table 3.2 and 3.3 means that no mutagenic effect was found. Sign "+” means that the number of revertants per litre is far lower than the amount of spontaneous revertants, but in the measurement a dose-response effect relation is visible. Values with added " $(+)$ " can be used for indication of a certain effect. In this way the measured values of 31 revertant per litre after ozone oxidation in Bad Honnef (II) are considered higher than the values from 17 revertants per litre in the sample before oxidation with ozone (17), as given in appendix 5, without considering a significant mutagenic effect.

The relatively moderate and strong mutagenic effect are described by "+" and "++" respectively.

The most spectacular result of the measurement is that the isolated acid hydrophilic material does not seem to be mutagenic for any water sample determined in the Ames test. The $\mathrm{pH} 7$ and $\mathrm{pH} 2$ fractions of the XAD isolation of the three surface water samples (Lekkanaal and Rhine Bad Honnef I and II) and of the water after chlorination (Andijk) expose clearly mutagenic effect. In the TA100 test only the water sample after chlorination is positive. 
After ozone oxidation of polluted surface water (Bad Honnef II) it seems that at $\mathrm{pH} 7$ a slight increase of the mutagenicity occurs (lower than the level of the spontaneous revertants) for TA-98 without S9 and a clear decrease for TA 98 and TA $100+$ S9.

Table 3.2 Results of the Ames test using test strain TA98

\begin{tabular}{|c|c|c|c|c|c|c|}
\hline \multirow[t]{2}{*}{ Sample } & \multicolumn{2}{|c|}{$\begin{array}{l}\text { Hydrophobic neutral } \\
\text { XAD pH } 7\end{array}$} & \multicolumn{2}{|c|}{$\begin{array}{l}\text { Hydrophobic acid } \\
\text { XAD pH } 2\end{array}$} & \multicolumn{2}{|c|}{ Hydrophilic acid material } \\
\hline & TA 98 -S9 & TA $98+$ S9 & TA $98-$ S9 & TA90+S9 & TA98-S9 & TA $98+$ S9 \\
\hline $\begin{array}{l}\text { Drinking } \\
\text { water }\end{array}$ & - & - & - & - & - & - \\
\hline Lekkanaal & + & ++ & + & + & - & - \\
\hline $\begin{array}{l}\text { Rhine Bad } \\
\text { Honnef I }\end{array}$ & + & ++ & + & ++ & - & - \\
\hline $\begin{array}{l}\text { Rhine Bad } \\
\text { Honnef II }\end{array}$ & $(+)$ & ++ & $(+)$ & $(+)$ & - & - \\
\hline $\begin{array}{l}\text { As above } \\
\text { after ozone } \\
\text { oxidation }\end{array}$ & $(+)$ & - & $(+)$ & - & - & - \\
\hline $\begin{array}{l}\text { Leiduin } \\
\text { before } \\
\text { ozonation }\end{array}$ & - & - & $(+)$ & - & - & - \\
\hline $\begin{array}{l}\text { Leiduin after } \\
\text { ozonation }^{1)}\end{array}$ & - & - & - & - & - & - \\
\hline $\begin{array}{l}\text { Andijk after } \\
\text { chlorination }\end{array}$ & $++^{3)}$ & $(+)$ & + & - & - & - \\
\hline 1) & \multicolumn{6}{|c|}{ dosing $0.8 \mathrm{mg} / \mathrm{L}$} \\
\hline 2) & \multicolumn{6}{|c|}{ dosing $1.5-2.5 \mathrm{mg} / \mathrm{L}$} \\
\hline 3) & at the highe & oncentration & toxic effect & the concent & occurred & \\
\hline
\end{tabular}

Table 3.3 Results of the Ames test using test strain TA100

\begin{tabular}{lllllll}
\hline Sample & \multicolumn{2}{l}{$\begin{array}{l}\text { Hydrophobic neutral XAD } \\
\text { pH 7 }\end{array}$} & \multicolumn{3}{l}{$\begin{array}{l}\text { Hydrophobic acid } \\
\text { XAD pH 2 }\end{array}$} \\
\cline { 2 - 7 } & TA 98 -S9 & TA 98 +S9 & TA 98-S9 & TA90+S9 & TA98-S9 & TA 98 +S9 \\
\cline { 2 - 6 } $\begin{array}{l}\text { Rhine Bad } \\
\text { Honnef II }\end{array}$ & - & $(+)$ & - & $(+)$ & - & - \\
$\begin{array}{l}\text { As above } \\
\text { after }\end{array}$ & - & $(+)$ & - & - & - & - \\
ozonation & & & & & - & - \\
$\begin{array}{l}\text { Leiduin } \\
\text { before } \\
\text { ozonation1) }\end{array}$ & - & - & - & - & - \\
Leiduin after & - & & & & - \\
ozonation \\
$\begin{array}{l}\text { Andijk after } \\
\text { chlorination }\end{array}$
\end{tabular}

For less polluted water samples (Leiduin) no mutagenic effect was found for both the lipophilic and the hydrophilic material. Also no mutagenic effect was found in the hydrophilic polar part after ozone oxidation.

Regarding the Ames test the following should be mentioned. In the current (described) research the Ames test was used only to show a mutagenic effect. The Ames test is at this moment the most important short-term genotoxicity test. The Ames test by the prediction of carcinogenic effects gives a not negligible percentage of false negative as well as false positive results. That is why the Health 
Board advises to perform minimal two additional test next to the Ames test using so called eukariotic cells (for instance cells of mammalians) to detect the gene mutations and chromosome deviation. The results obtained up to now within RIWA research show however that supplementary tests do not change the conclusions on mutagenic activity derived from Ames test.

\subsection{The organic material and the mutagenicity in a scheme}

The results earlier described are schematically given in Figure 3.2. This scheme gives also the principle of the implemented isolation set-up.

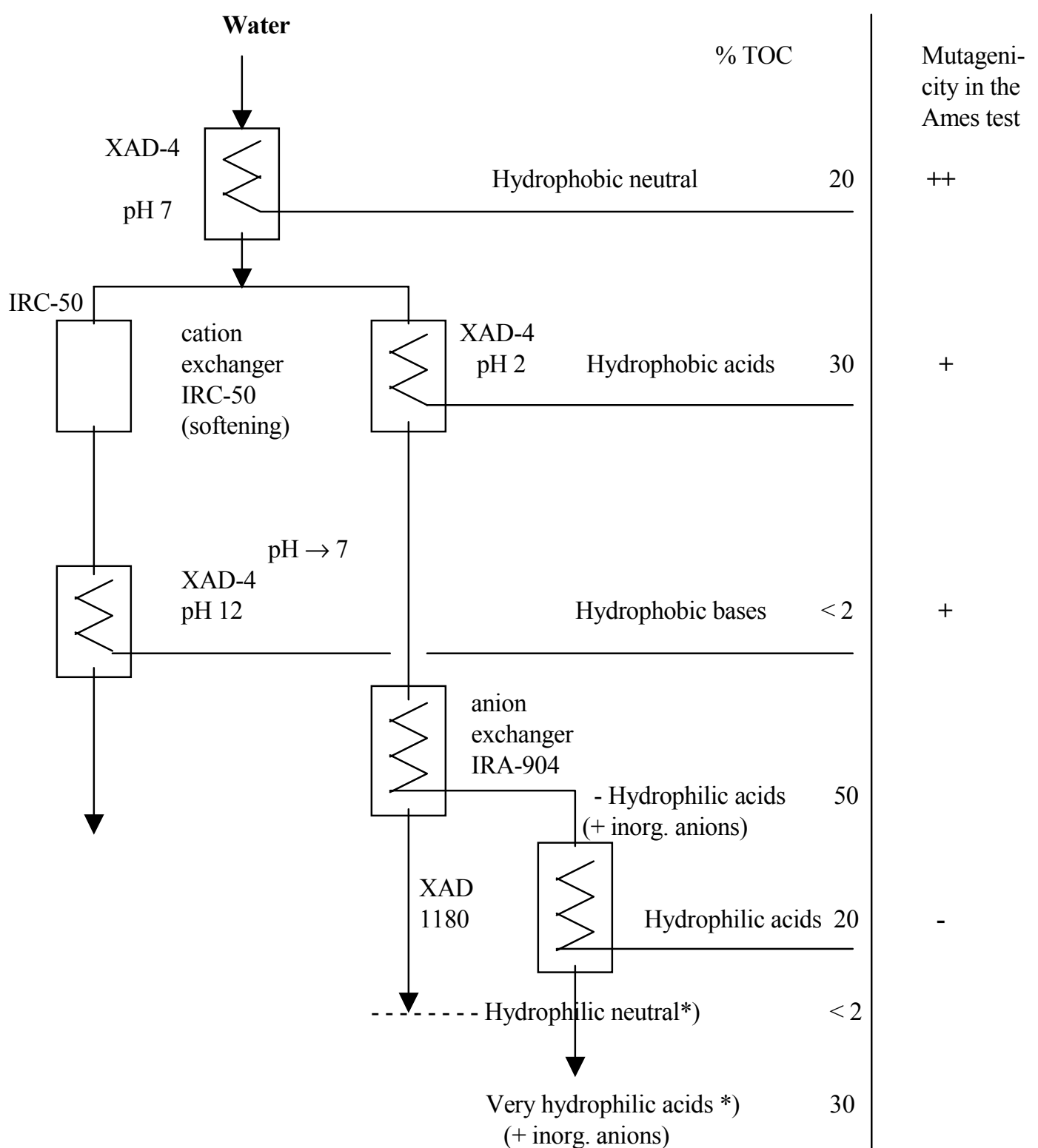

Figure 3.2 Isolation scheme of the organic package in water and occurrence of mutagenicity. *) = not possible to isolate 
The amount of the different classes of organic material are given as percentage of the TOC. It is also given in which fraction the mutagenicity was found.

\subsection{Availability hypothesis}

Based on the earlier findings (Noordsij, 1996), the results just shown and current insights into the transport of compounds via biological membranes (see appendix 1) it can be concluded, that the measured mutagenic effect $(\mathrm{Me})$ of a genotoxical compound in the Ames test is a function of mutagenic potential $(\mathrm{Mp})$ determined by the molecular structure and the rate $(\mathrm{V})$ with which the compound passes the membrane. Above bases also on the well known biological dose-timeresponse relations.

The rate with which a (lipophilic) organic compound passes the membrane, has a direct relation with the solubility of the compound in the cell wall, and resulting the lipophility of the cell wall material and the $\log \mathrm{K}_{\mathrm{ow}}$ of the organic compound. In other words, the mutagenic effect of the compound is determined by the $\log \mathrm{K}_{\mathrm{ow}}$ value and by the mutagenic potential determined in turn, by (parts of) molecular structure. When the lipophility of the potential mutagenic compound is approximately the same as the lipophility of the cell wall a mutagenic effect will occur. When the same lipophility differs sufficiently from this of the cell wall, no mutagenic effect occurs because the compound cannot reach the DNA material in the cell. Because of the nature of the cell wall, both strong hydrophilic and strong lipophilic compounds are not able to pass the cell wall (see also appendix 1).

When the above mentioned hypothesis is correct, it would mean that hydrophilic organic compounds with a relatively high molecular weight $(\mathrm{MW}>100)$ and $\operatorname{low} \log \mathrm{K}_{\mathrm{ow}}$ values $(<0)$ cannot pass the cell wall and induce any measurable revertant in the Ames test. From (geno)toxicological point of view the hydrophilic compounds with a MW $<100$ are probably also less relevant.

The following marginal notes should be listed regarding the hypothesis:

- the conclusions that hydrophilic compounds from (geno)toxicological point of view are less relevant, can be drawn only when a negative result was also obtained in other short term mutagenicity tests (see also 3.3)

- The relation between the mutagenic effect of a compound and the solubility in the cell membrane can be implemented for the passive transport through the membrane (see appendix 1). Active transport is not possible for the compounds isolated with XAD.

- The hypothesis does not count for inorganic compounds, such as bromate. The passage of ions is determined by active transport or by the existing trans-membrane potential. Bromate is a genotoxical carcinogenic compound. The genotoxical effects were found in tests with eukariotic cells and laboratory animals. Potassium bromate turned out to be weak positive for the strain TA100 in the Ames test after metabolic activating. The result was negative in the tests with the strains TA98, TA1535, TA1537 and TA1538 (see summary of the toxicity of bromate Kruithof et al., 1992). Inorganic compounds cannot be isolated with XAD.

- Finally, it should be mentioned that the cell wall of the Salmonella bacteria used in the Ames test is slightly modified to increase the accessibility for compounds with a relatively high molecular weight. This change does not have perhaps any influence on the conclusion drawn for the hydrophilic compounds. There was after all no mutagenic activity found with the hydrophilic fractions. 
When the hypothesis is true, it implicates that mutagenic compounds as determined with the Ames test are found only in the material isolated with XAD. Perhaps a continuation research with radioactive labelled material can finally decide.

\subsection{The influence of oxidation on the mutagenic effect}

Organic compounds become more hydrophilic after oxidation. In other words, the compounds shift on the $\log \mathrm{K}_{\mathrm{ow}}$ scale from low to higher values. Due to this, the velocity that these compounds pass the membrane changes and as result also a measured mutagenic effect.

It turned out in earlier performed research (Noordsij, 1996) that a discovered mutagenicity in surface water occurred together with a clear industrial pollution measured with GC-MS. The measured mutagenicity could however not be explained here from the identified compounds. The $\log \mathrm{K}_{\mathrm{ow}}$-value of the mutagenic fractions was always lower than of the contaminants measured with GC-MS. It can indicate that the mutagenic compounds are formed by oxidation of the industrial contaminants: promutagens are oxidised to mutagens.

In the same way it is also possible using an enhanced oxidation with ozone to form mutagenic compounds from industrial contaminants. But then also because of oxidation the $\log \mathrm{K}_{\mathrm{ow}}$ of mutagenic compounds can be lowered to such a value that a mutagenic effect disappears. The considered compounds can in such a case not pass the cell membrane.

The measured results obtained for the water samples Rhine Bad Honnef II before and after ozone oxidation illustrate the above described. For industrially polluted surface water a slight increase of the mutagenic effect in the $\mathrm{pH} 7$ fraction tested without the metabolic activation system (S9-fraction) appeared after ozone oxidation and a decrease in the $\mathrm{pH} 7$ fraction with metabolic activation. Taking into account the fact that both fractions are classified as non-mutagenic based on definition, but there is a clear dose-response relation, the mentioned change should be seen as an indication.

The increase in the $\mathrm{pH} 7$ fraction without metabolic activation can be caused by non-mutagenic contaminants, having a mutagenic potential in their molecular structure (so called pro-mutagens), of which the permeation velocity is too low but as a result of the ozone oxidation can pass the cell wall of the tested organism. This means that the presence of promutagenic, mainly industrial contaminants, can introduce mutagenic activity during ozone oxidation. An example is benz $(\alpha)$ pyrene. This compound becomes mutagenic in the Ames test after metabolic activation with S9. The $\log \mathrm{K}_{\text {ow }}$ value of benz $(\alpha)$ pyrene of approximately 4.8 is lowered by oxidation to a value $<$ 2.5 .

Promutagenic compounds are, because of their relatively high $\log \mathrm{K}_{\mathrm{ow}}$ value (>3.5), better to isolate from water and to analyse than the stronger hydrophilic mutagenic compounds with a lower $\log \mathrm{K}_{\mathrm{ow}}$-value (ca. 1.5). When during production of drinking water a possibly applied oxidation with ozone is proceeded by filtration (activated carbon filtration, soil filtration, dune filtration) the lipophilic promutagenic compounds will be removed, due to which no mutagenic compound can be formed.

The decrease of the mutagenic effect in the $\mathrm{pH} 7$ fraction after metabolic activation with $\mathrm{S} 9$ can be a cause of the fact that mutagenic compounds with a $\log \mathrm{K}_{\text {ow }}$ of approximately 1.5 in the water sample are oxidised by ozone oxidation to compounds with $\log \mathrm{K}_{\mathrm{ow}}$ values smaller than 0.5 .

The influence of the ozone oxidation on the mutagenic effect is to compare with the metabolic activation with the S9 fraction in the Ames test. The metabolic activation of promutagens is a form of oxidation, whereby the $\log \mathrm{K}_{\text {ow }}$-value is lowered to such values (and thus the hydrophility is increased) that the oxidised compounds can pass the cell wall of the Salmonella bacteria. 


\subsection{Origin and amount of the hydrophilic material}

The isolated and tested compounds described in this report had a weak hydrophilic acid character and formed approximately $20 \%$ of the total organic material present in water. Regarding hydrophility they are close to the less lipophilic fraction of the material isolated with XAD.

Using a HPLC fingerprint (appendix 4) the difference in physical characteristics between material isolated with XAD and tested hydrophilic material is shown. In these fingerprints it is made clear that in both XAD isolates the compounds are remarkably less hydrophilic than in the hydrophilic concentrate after ion exchange.

\subsection{Mutagenicity}

A mutagenic activity was not exposed in none of the examined hydrophilic fractions with the Ames test. Also not when in the lipophilic XAD isolates a relatively high activity was measured, like in the samples of Bad Honnef and the Lekkanaal. The Ames test with TA100 for chlorinated water gave the same picture. Also ozone oxidation of both, pre-treated and raw (industrially polluted) surface water did not introduce any mutagenic activity in the hydrophilic isolates.

The measurement results form a further base for the availability hypothesis described in this report. This says that the mutagenic effect in the Ames test depends on the velocity that the compound passes the cell wall (the rate of lipophility) and the mutagenic potential determined by the molecular structure.

When the lipophility of a compound influenced by certain oxidative or reductive processes becomes approximately the same as this of the cell wall (log $\mathrm{K}_{\mathrm{ow}}$ ca. 1.5), enabling to pass the cell membrane, a mutagenic effect can occur. A condition here is that mutagenic potential exists in the molecular structure. On the other hand it means however, that the 
lipophility of a mutagenic compound can be changed in such a way, that the $\log \mathrm{K}_{\mathrm{ow}}$-value will differ of this of the cell wall. Due to this the compound cannot or hardly pass the cell membrane resulting that no mutagenic effect can be measured.

Ozone oxidation of contaminated water with the mutagenic compound can lower the mutagenic activity, under condition that no promutagens (contaminants with a higher log $\mathrm{K}_{\mathrm{ow}}$-value) are present. On the other hand ozone oxidation of industrially polluted water can introduce a mutagenic effect.

\subsection{The meaning of the results to evaluate the drinking water quality and treatment}

Based on the results obtained up to now the total organic material can be divided into three categories of compounds:

a. Compounds with $\log \mathrm{K}_{\mathrm{ow}}$ value $<3$. These compounds are relatively easily to measure using the usual analysis techniques (for instance GC/MS). They are good removable from water and the most probably do not cause any mutagenic effect.

b. Compounds with $\log \mathrm{K}_{\mathrm{ow}} 3$ to 0 . Compounds from this category can be also possibly formed by oxidation of, among the others, mentioned compounds. They can be mutagenic in the Ames test. They are more difficult to remove from water using conventional techniques. The mutagenicity can be decreased using for instance (second step) ozone oxidation. They can be measured in a best way using LC/MS.

c. Compounds with $\log \mathrm{K}_{\mathrm{ow}}$ value $<0$. These compounds are mobile and not easy to remove during water treatment. They are difficult to analyse and from health point of view possibly less relevant.

In the current treatment practice to lower the amount of bromate formed, mainly by use of ozone, oxidation followed by a filtration step (activated carbon filtration) is implemented. Taking into account above drawn conclusions it deserves attention to check with which methods and in which rate the lipophilic compounds can be removed in the treatment scheme before the oxidation step.

Except of the recommendation for the treatment, the results are also important for the strategy of water quality monitoring. It can be concluded that the operating XAD and related methods are well suitable for the isolation of relevant mutagenic organic compounds from water.

To get a deeper insight into mutagenicity in water, attention has to be paid mainly on the identification of moderate polar mutagenic compounds (in the XAD isolates) using LC/MS and not particularly on the development of the isolation techniques for hydrophilic compounds.

From monitoring point of view of surface water quality in relation to drinking water it is recommended to involve the effluent of wastewater treatment plants. 


\section{Literature}

Beveren, J. van, Noordsij, A. Qualitative evaluation of the XAD isolation and chemical characterisation of the not isolated material using ion exchange. Nieuwegein 1992 (Kiwa) SWI 92.166 (in Dutch)

Beveren, J. van, Noordsij, A. Isolation of hydrophilic compounds in (drinking) water. Nieuwegein (Kiwa) 1999 SWI 99.140 (in Dutch)

Kruithof, J.C., Dijk-Looijaard, A.M. van, Genderen, J. van, Jagt, H. van der and Schippers, J.C. Formation of bromate during ozonation and implementation of other chemical desinfection methods. Nieuwegein (Kiwa) 1992 SWE 92.007 (in Dutch)

Leenheer, J.A. e.a. Comprehensive Approach to Preparative Isolation and Fractionation of Dissolved Organic Carbon from Natural Waters and Wastewaters. Environmental Science and Technology, 1981, Vol. 15, No. 5, 578 - 587.

Leo, A., Hansch, C. and Elkins, D. Partition coefficients and their uses." Chemical Reviews, 1971, Vol. 71 , No. 6.

Noij, Th.H.M. e.a.; Drinking water from surface water. Comment nr. 107, Nieuwegein (Kiwa) 1989 (in Dutch).

Noordsij, A. Rhine in the Netherlands. An analytical-chemical and toxicological research of the surface water Nieuwegein (Kiwa) 1991, SWE 90.030 (in Dutch)

Noordsij, A. Organic compounds in (drinking) water. Evaluation of 15 years VEWIN-research. Nieuwegein (Kiwa) 1996 SWE 96.003 (in Dutch)

OECD Guideline for the testing of chemicals: The Bacterial Reverse Mutation Test, adopted $21^{\text {st }}$ July 1997.

RIWA (1977 to 1986) Yearly RIWA-reports regarding the research on the contamination of the rivers Rhine and Maas (in Dutch). 


\section{Appendix 1}

\section{The Ames test and the transport of compounds through biological membranes}

The Ames test is a so-called Bacterial Reverse Mutation Test for the detection of compounds causing gene mutation (changes within a gene, like the exchange of the base pair in the DNA by another base pair and the loss of a piece of the DNA). Modified Salmonella bacteria are used in the Ames test. Their DNA is changed in such a way, that the cell is not able anymore to produce the necessary amino acid histidine for the cell division. The cell will then not divide based on the substrate matrix.

During the performance of the Ames test, a concentrate of the organic compound being under investigation is brought in contact with the mutated Salmonella bacteria. When a mutagenic compound enters the cell, it will affect the modified part of DNA and re-mutate the DNA. Due to this the histidine production is possible again and the cell division can again occur. The magnitude of the cell division is a measure of the mutagenicity of the tested material. This is expressed in the amount of revertants (= 'conversion' of mutated bacteria to a normal functioning ones) per litre water.

Two strains used in the Ames test have the code name TA98 and TA100. TA98 is mainly used for the detection of mutagenic compounds present in the surface water and TA100 for mutagenic compounds, formed during desinfection (chlorination) of water.

Higher organisms (like mammalians and humans) have got a number of enzyme systems, which can convert foreign compounds and endogenous metabolic waste products in more soluble compounds which can be easier secreted. This phenomena is called metabolic activation and the belonging processes fall under the term biotransformation. Biotransformation reactions can be divided into phase I reactions (oxidation, reduction, hydrolysis) introducing a polar group in the molecule and phase II reaction (conjugations) which conjugate an endogenous hydrophilic compound with the polar group in the molecule. 
The conjugated product is soluble in water. Strong lipophilic compounds are first mainly stored in the adipose tissue. During the detoxification process also compounds can be formed, more harmful for the body than original compounds. Regarding genotoxical compounds it means that non harmful promutagenic compounds are transformed into mutagenic metobolites (metabolism products). An important role during the oxidation of foreign, lipophilic compounds has the enzyme cytochrome P 450. This enzyme forms a fraction of the so-called mixed function oxidase (MFO) system.

The Salmonella bacteria as used in the Ames test do not have the mentioned enzyme system. To see the effect of this system on the examined compound, an enzyme preparation from rats' liver, so called S9 mix is added (the enzyme is concentrated in the supernatant of a rats' liver homogenate after centrifugation with a power comparable to $G=9$ ). For this $S 9$ mix certain promutagenic compounds are transformed to mutagenic compounds or mutagenic compounds get inactivated.

To reach the genetic material (DNA) of the Salmonella bacteria used in the Ames test, an organic compound has first to pass the cell membrane of the bacteria. During this passage the membranes behave as semi permeable barriers. This means that some compounds can pass this barrier easily while for the others it is difficult or impossible. The passage is determined by physical-chemical properties of the membrane and compounds.

The various types of cell membranes of living organisms are strongly related concerning their structure but regarding permeability properties, clear differences can be seen. The most membranes have got the character of lipid membranes. These membranes are built of a discontinuous bi-molecular lipid layer, where in between and around protein molecules are placed. The lipids consist mainly of phospolipids and contain lipophilic (fatty acids rests) and hydrophilic (phosphoric acid rests) groups. This double character results in a structural organisation of two layers lipid molecules, where the lipophilic chains are turned to each other and surrounded by other lipophilic chains, while the hydrophilic parts are oriented in direction of the outer and inner water surrounding. Also the proteins are bi-modal and oriented in such a way that the ionic, strongly polar groups are mainly situated on the membrane surface and the lipophilic rests in the lipophilic interior of the membrane. It is assumed that in the central axis of the proteins very narrow pores filled with water are present.

The mechanisms ruling the fact that foreign compounds can pass the membrane are passive and active diffusion, filtration, active transport and pinocytose.

Pinocytose is the enclosure of a foreign 'object' by the membrane and plays an important role by, for instance, removal of particles from the alveolus.

Lipophilic compounds pass the membrane mainly due to diffusion processes and active transport. During the passive diffusion process, the compound gets solved in the lipid phase of the membrane. The magnitude of transport depends, among others, on the concentration gradient, the size of molecule, the fat solubility $\left(\log \mathrm{K}_{\mathrm{ow}}\right)$ and to smaller extent on the temperature. Active diffusion and active transport take place via carrier molecules. Active transport asks energy and can expire because of a concentration drop.

Strong lipophilic compounds expose such a strong preference for a lipophilic environment, that they a) hardly solve in the water environment (and all passage processes take place in solution) and b) have strong preference to accumulate in the lipophilic environment (for instance adipose tissue).

Hydrophilic compounds with a MW $<100$ can pass the cell membrane via the pores (via filtration). The driven force is here hydrostatic or osmotic. The partition coefficient does not play here any role. In comparison to the diffusion process, filtration does not mean a lot in 
the toxicology. Strong hydrophilic compounds with a MW $>100$ have got a clear preference of the hydrous phase that they hardly or not at all pass the lipid membrane.

Compounds in ion form cannot pass the cell membrane easily. This has consequences for xenobiotic compounds in form of acids, base and salts. It is proved that the hydrophilic organic compounds in water consist mainly of acids (Noordsij, 1996).

Based on above it can be stated that optimal physical-chemical properties of compounds for an efficient passage via lipid membrane are: a sufficient hydrophilic character to dissolve good in hydrous environment and sufficient lipophilic character to penetrate easily the lipophilic matrix of the cell membrane. 


\section{Appendix 2}

\section{Sampling locations and examined water types}

- Drinking water Nieuwegein $(05.08$ 1997)

- Lekkanaal water WRK (12.08.1997)

- Rhine water from Germany at Bad Honnef I (14.08.1997)

- Rhine water from Germany at Bad Honnef II (27.10.1998) *) **)

- Rhine water from Germany at Bad Honnef II (27.10.1998) after ozone oxidation *)

- GWA Leiduin dune filtrate before ozonation (24.09.1998)

- GWA Leiduin dune filtrate after ozonation (12.10.1998)

- PWN Water Andijk (Ijsselmeer) after chlorination (15.09.1998) to test with TA100

*) filtered through $0.5 \mu \mathrm{m}$ filter to remove suspended material before ozone oxidation. with $1.4 \mathrm{mg} / \mathrm{L}$ ozone

**) TOC in filtrate is $3.4 \mathrm{mgC} / \mathrm{L}$. 


\section{Appendix 3}

\section{Quantification of adsorbed organic material}

UV measurements were performed in three water samples (drinking water, Lekkanaal and Bad Honnef I) in influent and effluent of the used adsorption column. Using these data an impression was gained of the amount of organic material involved in the various isolation steps. There was chosen for UV measurement (at $254 \mathrm{~nm}$ ) because TOC measurement in the XAD 1180 elution did not have much sense because of the used solvent ethanol. This quantification is thus limited to the present UV absorbing material.

It turned out in earlier performed research that the majority of the organic material isolated with XAD (more than 80\%) is of natural origin (Noij et al., 1989, Noordsij, 1991).

The difference between the influent and effluent of the IRA-904 column is the amount of the hydrophilic acid material bound to the ion exchange.

Comparison of these values with the amount of organic material in the recovered XAD-1180 elution gives a picture of the amount of material, involved finally in the toxicity test.

UV measurements in the influent and effluent of the ion exchange column are given in Table 1. The yield of the XAD elution and sample reprocessing measured according to this method is approximately $40 \%$ of the hydrophilic acid material adsorbed to the ion exchanger. The latter is approximately the half of the total hydrophilic acid material found in water (see chapter 1.3 ) or in other words, the measured hydrophilic material is approximately $20 \%$ of the total organic material present in water.

The isolated and elutriated hydrophilic fraction from XAD-1180 is of the same magnitude as isolated material with the XAD at $\mathrm{pH} 7$, namely circa $20 \%$ of the total organic material. The remaining amount of not isolated material is strongly hydrophilic and amounts ca. $30 \%$ of the TOC. 
Table 1 Yield of the isolation of lipophilic and hydrophilic compounds measured with UV (254 nm)

\begin{tabular}{|c|c|c|}
\hline $\begin{array}{l}\text { Water sample and isolation } \\
\text { technique }\end{array}$ & $\mathrm{UV}$ in $\mathrm{E} / \mathrm{m}$ & $\begin{array}{l}\text { Recovered from XAD- } \\
1180 \\
\text { Amount in \% }\end{array}$ \\
\hline \multicolumn{3}{|l|}{ Drinking water } \\
\hline Before IRA-904 & 4.05 & \\
\hline After IRA-904 & 0.80 & \\
\hline On IRA-904 & 3.25 & \\
\hline Elution XAD-1180 & 1.40 & 43 \\
\hline \multicolumn{3}{|l|}{ Lekkanaal } \\
\hline Before IRA-904 & 5.15 & \\
\hline After IRA-904 & 1.30 & \\
\hline On IRA-904 & 3.85 & \\
\hline Elution XAD-1180 & 1.40 & 36 \\
\hline \multicolumn{3}{|l|}{ Rhine Bad Honnef (I) } \\
\hline \multicolumn{3}{|l|}{ Before IRA-904 } \\
\hline \multirow[t]{2}{*}{ After IRA-904 } & 4.65 & \\
\hline & 1.35 & \\
\hline On IRA-904 & - & \\
\hline Elution XAD-1180 & 3.30 & \\
\hline
\end{tabular}




\section{Appendix 4}

\section{Chromatografic characterisation of isolated material}

In figures $1 \mathrm{a}, 1 \mathrm{~b}$ and $1 \mathrm{c}$ the HPLC chromatograms ('finger prints') of both lipophilic XAD isolates and the hydrophilic concentrate isolated with the combination IRA-904 and XAD-1180 (Rhine water, Bad Honnef I) are given.

The retention time (horizontal axis) is an indication of the transition from hydrophilic to lipophilic character of the compounds. In both XAD isolates the most compounds have a significantly higher retention time ( $>10$ minutes) than in the hydrophilic concentrate after ion exchange (the majority of the detected material $<10$ minutes). 
Rhine XAD pH 7

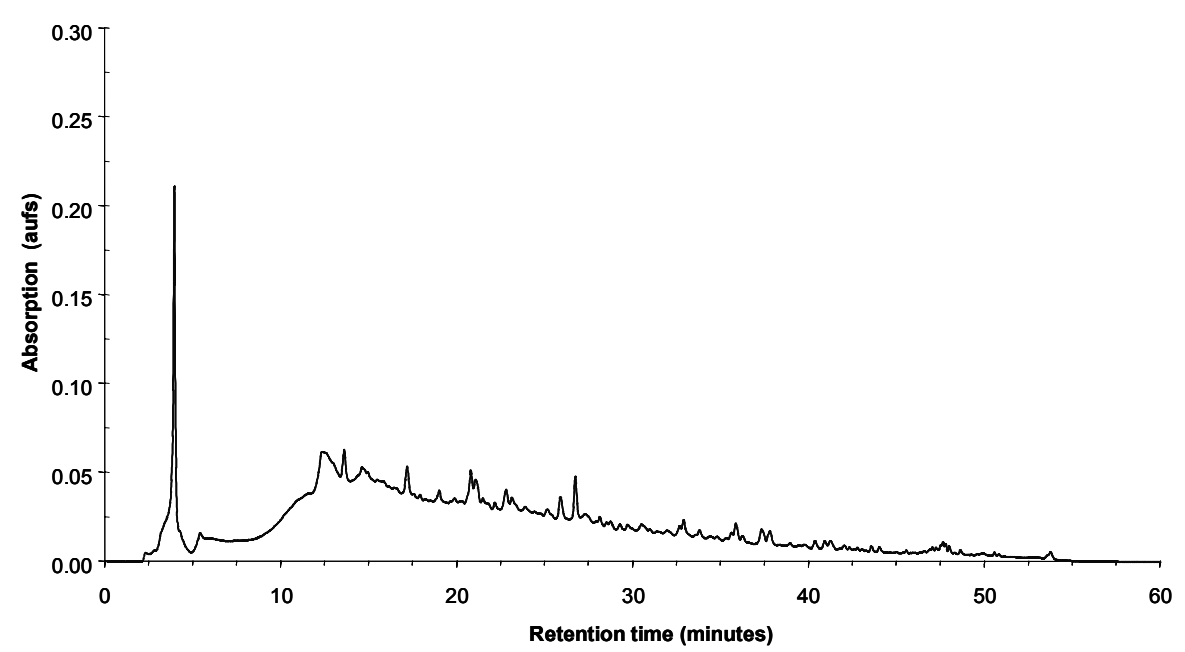

Figure 1a HPLC finger prints of lipophilic neutral compounds (XAD $4 \mathrm{pH}$ 7) in Rhine river, Bad Honnef I

Rhine XAD pH 2

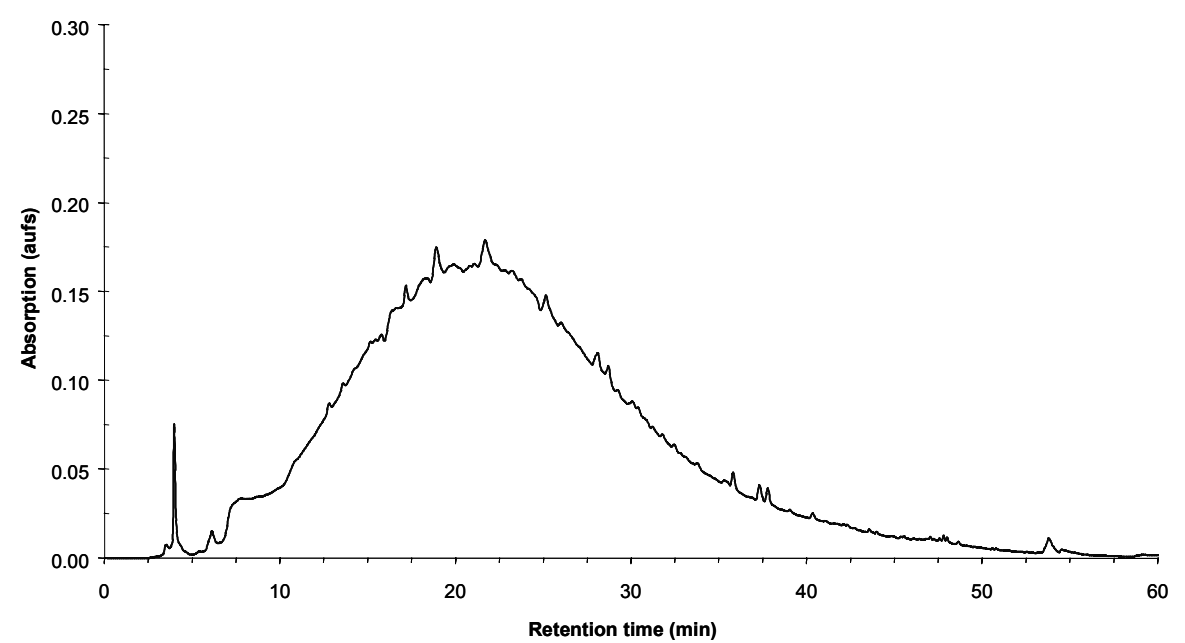

Figure 1b HPLC finger prints of lipophilic acidic (XAD 4 pH 2) material in Rhine water, Bad Honnef I 


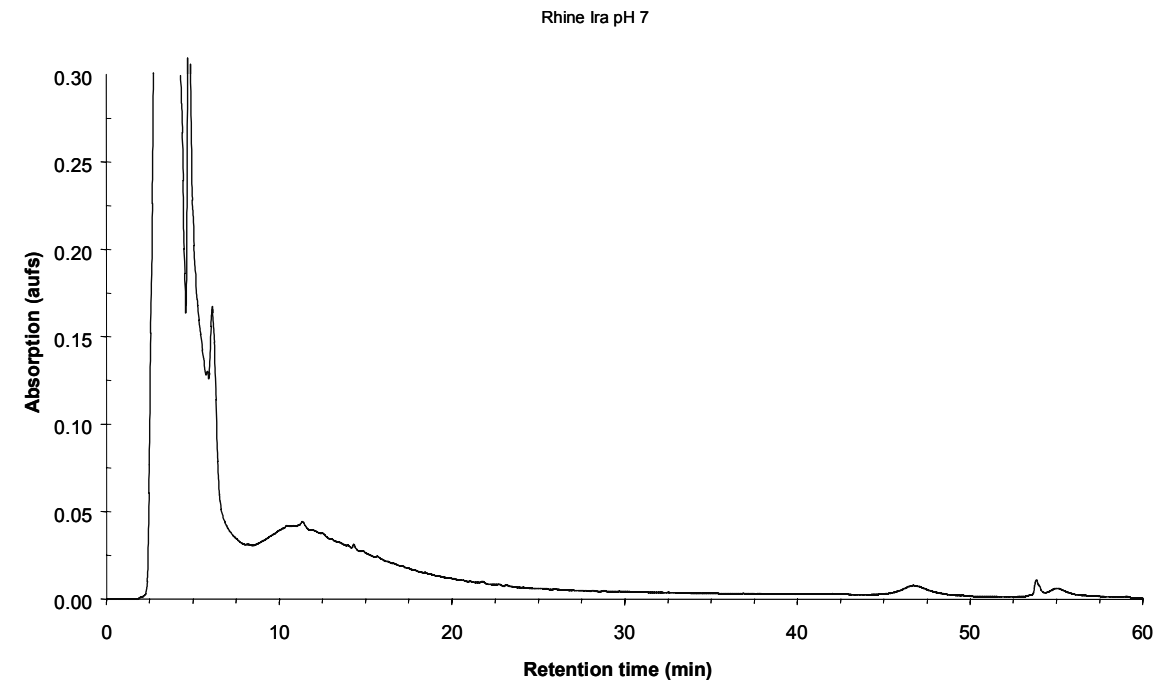

Figure 1c HPLC finger prints of hydrophilic acidic (IRA pH $7+$ XAD-1180) material in Rhine water, Bad Honnef I 


\section{Appendix 5}

\section{Results Ames test}

The results of the Ames test with the strains TA98 and TA100 with and without metabolic activation (S9 - mix) are shown in Tables 1 and 2. The test strain TA98 is specifically sensitive to contaminants in surface water, while TA100 is mainly sensitive to mutagenic products formed by chlorination of water.

Also the spontaneous revertans for the various test series are reported. The measured data are corrected for the spontaneous revertants. A measurement is considered as mutagenic positive, when a number of revertants amounts at least twice the amount of spontaneous revertants, and when a dose response effect relation is considered.

With (-) it is given that no mutagenic effect was observed. The measured data between brackets () mean that the amount of revertants (after correction for spontaneous revertants) is smaller than the amount of spontaneous revertants but that there is a dose -response relation. The significantly positive mutagenic effects are given in bold and underlined. The remaining data are of the same order of magnitude as of spontaneous revertants. They indicate a minimal mutagenic effect. 
Table 1 Results of the Ames tests with test stream TA98

\begin{tabular}{|c|c|c|c|c|c|c|}
\hline \multirow[t]{2}{*}{ Sample } & \multicolumn{2}{|c|}{$\begin{array}{l}\text { Hydrophobic } \\
\text { XAD - pH } 7\end{array}$} & \multicolumn{2}{|c|}{$\begin{array}{l}\text { Hydrophobic } \\
\text { XAD- } \mathrm{pH} 2\end{array}$} & \multicolumn{2}{|c|}{$\begin{array}{l}\text { Hydrophilic acid } \\
\text { material }\end{array}$} \\
\hline & $\begin{array}{l}\text { TA } 98 \\
- \text { S9 }\end{array}$ & $\begin{array}{r}\text { TA } 98 \\
+ \text { S9 }\end{array}$ & $\begin{array}{l}\text { TA } 98 \\
\text { - S9 }\end{array}$ & $\begin{array}{l}\text { TA } 98 \\
+ \text { S9 }\end{array}$ & $\begin{array}{c}\text { TA } 98 \\
- \text { S9 }\end{array}$ & $\begin{array}{r}\text { TA } 98 \\
+ \text { S9 }\end{array}$ \\
\hline $\begin{array}{l}\text { Spontaneous revertants } \\
(09-09-1997)\end{array}$ & 39 & 52 & 39 & 52 & 39 & 52 \\
\hline $\begin{array}{l}\text { Drinking water } \\
(05-08-1997)\end{array}$ & $(-)$ & $(-)$ & $(-)$ & $(-)$ & $(-)$ & $(-)$ \\
\hline $\begin{array}{l}\text { Lekkanaal } \\
(12-08-1997)\end{array}$ & 44 & $\underline{150}$ & 37 & 52 & $(-)$ & $(-)$ \\
\hline $\begin{array}{l}\text { Rhine Bad Honnef (I) } \\
\text { (14- 08-1997) }\end{array}$ & 47 & $\underline{\mathbf{3 3 3}}$ & 40 & $\underline{102}$ & $(-)$ & $(-)$ \\
\hline $\begin{array}{l}\text { Spontaneous revertants } \\
(--11-1998)\end{array}$ & 41 & 48 & 41 & 48 & 41 & 48 \\
\hline $\begin{array}{l}\text { Rhine Bad Honnef (II) } \\
(27-10-1998)\end{array}$ & (17) & $\underline{76}$ & (16) & (33) & $(-)$ & $(-)$ \\
\hline $\begin{array}{l}\text { Idem after ozone } \\
\text { oxidation }\end{array}$ & (31) & $(-)$ & (17) & $(-)$ & $(-)$ & $(-)$ \\
\hline $\begin{array}{l}(27-10-1998) \\
\text { Spontaneous revertants }\end{array}$ & 39 & 47 & 39 & 47 & 39 & 47 \\
\hline $\begin{array}{l}(--11-1998) \\
\text { Leiduin before ozone }\end{array}$ & $(-)$ & $(-)$ & (11) & $(-)$ & $(-)$ & $(-)$ \\
\hline Leiduin after ozone & $(-)$ & $(-)$ & $(-)$ & $(-)$ & $(-)$ & $(-)$ \\
\hline $\begin{array}{l}(12-10-1998) \\
\text { Andijk after chlorination } \\
(15-09-1998)\end{array}$ & $138 *)$ & (30) & 46 & $(-)$ & $(-)$ & $(-)$ \\
\hline
\end{tabular}

Table 2 Results of the Ames tests with test stream TA100

\begin{tabular}{llcccc}
\hline Sample & $\begin{array}{c}\text { Hydrophobic neutral } \\
\text { XAD- pH 7 }\end{array}$ & $\begin{array}{c}\text { Hydrophobic acid } \\
\text { XAD-pH 2 }\end{array}$ & $\begin{array}{c}\text { Hydrophilic acid } \\
\text { material }\end{array}$ \\
\hline TA 100 & TA 100 & TA100 & TA 100 \\
- S9 & + SA & - S9 100 & TA100 \\
+ S9 & - S9 & + S9 \\
\hline
\end{tabular}




$\begin{array}{lcccccc}\begin{array}{l}\text { Spontaneous revertants } \\ (--11-1998)\end{array} & 139 & 150 & 139 & 150 & 139 & 150 \\ \begin{array}{l}\text { Rhine Bad Honnef (II) } \\ (27-10-1998)\end{array} & (-) & (40) & (-) & (15) & (-) & (-) \\ \begin{array}{l}\text { Idem after ozonisation } \\ (27-10-1998)\end{array} & (-) & (16) & (-) & (-) & (-) & (-) \\ \begin{array}{l}\text { Spontaneous revertants } \\ (--10-1998)\end{array} & 154 & 154 & 154 & 154 & 154 & 154 \\ \begin{array}{l}\text { Leiduin before ozone } \\ (24-09-1998)\end{array} & (-) & (-) & (-) & (-) & (-) & (-) \\ \begin{array}{l}\text { Leiduin after ozone } \\ (12-10-1998)\end{array} & (-) & (-) & (-) & (-) & (-) & (-) \\ \begin{array}{c}\text { Andijk after chlorination } \\ (15-09-1998)\end{array} & \underline{\mathbf{7 1 2}} *) & (126) & \left.\underline{\mathbf{3 1 2}}^{*}\right) & (107) & (-) & (-)\end{array}$

*) At higher concentration toxicity occurred. By these measurements the value does not result from more measurements but from the measured number of revertants per 1 litre equivalent dose. 